\title{
SLUDGE FROM RICE PARBOILING WASTEWATER TREATMENT PLANT AS ALTERNATIVE SUBSTRATE FOR THE PRODUCTION OF Araucaria angustifolia SEEDLINGS
}

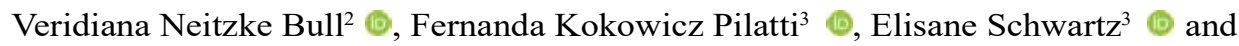 \\ Francine Ferreira Cassana ${ }^{3 *}$
}

\footnotetext{
${ }^{1}$ Received on 13.08.2020 accepted for publication on 29.01.2021.

${ }^{2}$ Instituto Federal Sul-rio-grandense, Graduada em Tecnologia em Gestão Ambiental, Pelotas, RS - Brasil. E-mail: <veridianabull@gmail. com>.

${ }^{3}$ Instituto Federal Sul-rio-grandense, Pelotas, RS - Brasil. E-mail: <fernanda.kop@gmail.com>,<elisane.schwartz@gmail.com> and $<$ francinecassana@gmail.com>.

*Corresponding author.
}

\begin{abstract}
The sludge produced by rice parboiling wastewater treatment plants has substantial amounts of nutrients and organic matter, therefore requiring proper environmental disposal. One option is to use it as an alternative substrate for the production of forest species seedlings. This study aimed to assess the viability of using the sludge from rice parboiling wastewater as an alternative substrate for the production of Araucaria angustifolia (Bertol.) O. Kuntze seedlings. A. angustifolia seeds were kept in vermiculite until sprouting, then transferred to polyethylene bags filled with five different substrates (treatments): $100 \%$ sand (T1); $75 \%$ sand and $25 \%$ sludge (T2); $50 \%$ sand and 50\% sludge (T3); $25 \%$ sand and 75\% sludge (T4); $100 \%$ sludge (T5). Each treatment had 10 replicates (bag with one seedling). Shoot system growth, hypocotyl diameter, root system growth and biomass were evaluated at 94, 180, and 300 days of growth. Data were subjected to Analysis of Variance (ANOVA) followed by Tukey test with a significance level of $5 \%$. Seedlings' growth was similar on treatments containing $25 \%, 50 \%$, and $75 \%$ sludge, while $100 \%$ sand and $100 \%$ sludge resulted in less growth at 300 days. In conclusion, the sludge from rice parboiling wastewater is suitable as an alternative substrate, and the ratio of $25 \%$ sand $+75 \%$ sludge could be recommended, for exploit larger amounts of the residue.
\end{abstract}

Keywords: Biosolids; Industrial waste; Plant growth.

\section{LODO DE ESTAÇÃO DE TRATAMENTO DE PARBOILIZAÇÃO DE ARROZ COMO SUBSTRATO ALTERNATIVO NA PRODUÇÃO DE MUDAS DE Araucaria angustifolia}

\begin{abstract}
RESUMO - O lodo produzido em estações de tratamentos de efluente de parboilização de arroz apresenta quantidades consideráveis de nutrientes e matéria orgânica, necessitando de uma destinação ambientalmente correta. Uma possibilidade é seu uso como substrato alternativo na produção de plantas de espécies florestais. $O$ objetivo deste estudo foi avaliar a viabilidade do uso de lodo advindo do tratamento do efluente de parboilização de arroz como substrato alternativo na produção de mudas de Araucaria angustifolia (Bertol.) O. Kuntze. Sementes de A. angustifolia foram colocadas em vermiculita até a germinação e, após, transplantadas para sacos de polietileno contendo cinco diferentes substratos (tratamentos): 100\% de areia (T1); 75\% de areia e 25\% de lodo (T2); $50 \%$ areia e $50 \%$ de lodo (T3); $25 \%$ de areia e $75 \%$ de lodo (T4) e $100 \%$ de lodo (T5). Cada tratamento possuía dez unidades amostrais (saco com uma muda). Ao final de 94, 180 e 300 dias de cultivo, foram realizadas avaliações do crescimento da parte aérea, diâmetro do hipocótilo, avaliações do crescimento do sistema radicular e biomassa. Os dados foram submetidos à análise de variância (ANOVA), seguido do teste de Tukey ao nivel de 5\% de significância. O crescimento das plântulas foi similar nos tratamentos contendo $25 \%$, $50 \%$ e $75 \%$ de lodo, enquanto $100 \%$ areia e $100 \%$ lodo proporcionaram menor desenvolvimento das plantas após 300 dias. Portanto, conclui-se que é viável o uso de lodo de tratamento de efluente de parboilização de arroz como substrato alternativo, sendo recomendado o uso de $25 \%$ de areia $+75 \%$ de lodo por destinar maior quantidade do resíduo.
\end{abstract}

Palavras-Chave: Biossólidos, Crescimento de plantas, Rejeito industrial.

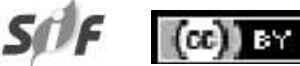

Revista Árvore 2021;45:e4510 http://dx.doi.org/10.1590/1806-908820210000010 


\section{INTRODUCTION}

About $25 \%$ of the rice consumed in Brazil comes from parboiling (Paraginski et al., 2014), a process that consists in pre-cooking the grains in potable water aiming to increase their yield and nutritive value (Volpe, 2014). Nevertheless, each kilogram of processed rice produces around four liters volume of wastewater (Nadaleti et al., 2018) with acidic pH and high levels of Biochemical Oxygen Demand, Chemical Oxygen Demand, and solids, that must be treated before returning to water bodies (Kumar et al., 2016). At the end of this process, a sludge waste is generated, whose composition includes organic substances and nutrients such as nitrogen and phosphorus (Faria et al., 2006).

Lately, there is a growing concern related to the organic and industrial waste disposal, which resulted in research that intends to exploit waste aiming to mitigate the environmental impacts that it could cause if inappropriate disposal occurred (Berilli et al., 2014). Then again there is greater demand for services and products related to the production of native forest species seedlings, whether to be used in degraded areas recovery, reforesting projects and/or environmental compensation (Caldeira et al., 2013). The production of seedlings must take into account the substrate, as plants will fix their roots in it and access nutrients and water, thus influencing the quality of the seedlings (Trigueiro and Guerrini, 2014; Siqueira et al., 2018).

To choose a substrate, their physical and chemical properties must be given consideration, so that it provides the plants a good development, but also economical aspects related to low cost and availability for acquisition (Delarmelina et al., 2014). Hence there is the possibility of using the sludge from rice parboiling wastewater treatment plants as substrate for the production of seedlings, as, according to Vieira et al. (2011), it contains minerals that may be used as nutrients by plants. Some studies use sewage sludge, or biosolid, as alternative substrate, which enables comparisons with that from rice industry (Abreu et al., 2019; Mendonça et al., 2019; Siqueira et al., 2018; Trigueiro and Guerrini, 2014; Caldeira et al., 2013).

A. angustifolia is a long-lived secondary species, commonly known as araucaria or Brazilian pine, naturally occurring in Brazil, spread throughout the states of Paraná (PR), Santa Catarina (SC) and Rio Grande do Sul (RS) (Gibinski and Krupek, 2016). According to Fritzsons et al. (2018), an area where the species occurs in Southern RS is Serra do Sudeste, which comprises the municipalities of Canguçu, Pelotas, Santana da Boa Vista and others. The species has great importance to biodiversity, in addition to the use of its seeds as food source by both fauna and human being. Due to its intensive wood exploitation, the species is now at extinction risk, classified as "in danger" by the Brazilian Endangered Flora List (BRASIL, 2014), and as critically endangered by the International Union for Conservation of Nature - IUCN (2018). In this way, it is legitimate the importance of research on the conservation and regeneration of $A$. angustifolia.

Considering the occurrence of this endangered native species in Serra do Sudeste area, where are also many rice industries, this study aimed to assess the viability of producing $A$. angustifolia seedlings using sludge from rice parboiling wastewater treatment at different proportion as substrate.

\section{MATERIAL AND METHODS}

The experiment was performed in a greenhouse at $31^{\circ} 42^{\prime} 56.2^{\prime \prime} \mathrm{S} 52^{\circ} 18^{\prime} 40.0^{\prime \prime} \mathrm{W}$. The average temperature was $14 \pm 3^{\circ} \mathrm{C}$ in the winter and $22 \pm 4^{\circ} \mathrm{C}$ in the summer.

A. angustifolia seeds were collected at May 24, 2018, at Passo Fundo National Forest, RS, and kept refrigerated $\left(4^{\circ} \mathrm{C}\right)$. On June 12,2018 , the seeds were subjected to the immersion test in water, and those potentially nonviable (buoyant) were taken off. The remaining was disinfected with sodium hypochlorite at $2 \%$ for 20 minutes. Seeds were then scarified to partially remove the tegument, aiming to accelerate germination and increase its synchrony (Ferreira and Handro, 1979). In order to minimize sample lost, seeds were placed in germination trays containing vermiculite at June 13, 2018 and, 36 days after, when their rootlets were around $5 \mathrm{~cm}$, they were individually transplanted to the experiment containers (polyethylene bags for seedlings, $6 \mathrm{~cm}$ diameter $\mathrm{x} 17$ cm height).

Containers were previously filled with one of five treatment mix (v:v): $100 \%$ sand (washed, medium size) (T1); $75 \%$ sand 25\% sludge (T2); 50\% sand 50\%

Revista Árvore 2021;45:e4510 
sludge (T3); $25 \%$ sand $75 \%$ sludge (T4); 100\% sludge (T5). Sludge was obtained from a rice parboiling wastewater treatment plant in a rice processing company located at Pelotas, RS (Some information on the sludge chemical composition is presented in Table 1).

Experimental design consisted of three groups referring to the periods of evaluation: 94, 180 and 300 days of plant growth. Each group comprised five treatments with 10 plants (replicates) each, in a total of 150 plants. All the containers were placed on a bench in a greenhouse, watered to saturation when necessary and randomly repositioned every 15 days. According to Oliveira et al. (2016), repositioning the plants avoids eventual imbalanced competition for light, where some plants, due to their sizes, could be less exposed to light than others.

At each period of evaluation (94, 180, 300 days), seedlings were removed from the plastic bags, had the substrate removed and their roots carefully washed with tap water. Seedlings were cut at the cotyledon insertion point, detached the shoot system from the radicular system, which was then separated into the main root and first order lateral roots. A metric ribbon was used to measure main shoot height, shoot system total length (main shoot height + lateral branches length), main root length, first order lateral roots average length, and root system total length; the number of lateral roots was also recorded, and hypocotyl diameter was measured with a pachymeter. Biomass was assessed through shoot system fresh matter, shoot system dry matter, main root fresh matter, main root dry matter, lateral roots fresh matter and lateral roots dry matter. Fresh roots and shoots were weighted in a semi-analytical scale, then dried in oven at $60^{\circ} \mathrm{C}$ until reach constant weight.

Data were submitted to Shapiro-Wilk's normality test and Bartlett's homoscedasticity test. Once those conditions were fulfilled, one-way analysis of variance (ANOVA) was performed and mean values were compared by Tukey test with significance level at $5 \%(p<0.05)$. All statistical analyses were performed using R version 3.6.2 (R Core Team, 2019).

\section{RESULTS}

Considering main shoot height and shoot system total length at 180 days, seedlings grown in sand (T1) had the smallest values $(19.73 \mathrm{~cm}$ and 29.03 $\mathrm{cm}$, respectively), while treatments with sludge had greater results, although no significant difference was observed between them (Table 2). At 300 days, T2, $\mathrm{T} 3$, and $\mathrm{T} 4$ had no significant difference, but provided greater results in shoots and, as consequence, had greater shoot system total length. Thus, considering

Table 1 - Physicochemical characterization of sludge from rice parboiling wastewater treatment.

Tabela 1 - Caracterização físico-química do lodo da estação de tratamento de efluente de parboilização de arroz.

\begin{tabular}{|c|c|c|c|c|}
\hline \multicolumn{5}{|l|}{ Physicochemical } \\
\hline Assay & $\mathbf{R}$ & $\mathbf{U}$ & LOQ & $\mathbf{R V}$ \\
\hline Total soluble phenols & 0.05 & $\mathrm{mg} / \mathrm{L}$ & 0.01 & $\overline{0.01}$ \\
\hline Free liquids in total mass & $<0.1$ & $\mathrm{~mL}$ & 0.1 & - \\
\hline Soluble nitrate (expressed as N) & 1.0 & $\mathrm{mg} / \mathrm{L}$ & 0.3 & 10.0 \\
\hline Oils and greases in total mass & $<10$ & $\mathrm{mg} / \mathrm{L}$ & 10.0 & - \\
\hline Solids & 76.4 & $\%$ & 0.3 & - \\
\hline $\mathrm{pH}$ in total mass & 6.25 & - & $0-14$ & 2 to 12.5 \\
\hline Soluble sulphate (expressed as $\mathrm{SO}_{4}$ ) & $<1.0$ & $\mathrm{mg} / \mathrm{L}$ & 1.0 & 250.0 \\
\hline Soluble surfactants & 0.760 & $\mathrm{mg} / \mathrm{L}$ & 0.4 & 0.5 \\
\hline \multicolumn{5}{|l|}{ Metals } \\
\hline Assay & $\mathbf{R}$ & $\mathbf{U}$ & LOQ & $\overline{R V}$ \\
\hline Soluble Al & $<0.2$ & $\mathrm{mg} / \mathrm{L}$ & 0.2 & 0.2 \\
\hline Soluble Cu & $<0.05$ & $\mathrm{mg} / \mathrm{L}$ & 0.05 & 2.0 \\
\hline Soluble Fe & 8.5 & $\mathrm{mg} / \mathrm{L}$ & 0.1 & 0.3 \\
\hline Soluble $\mathrm{Na}$ & 43.7 & $\mathrm{mg} / \mathrm{L}$ & 1.0 & 200.0 \\
\hline Soluble Zn & 0.180 & $\mathrm{mg} / \mathrm{L}$ & 0.1 & 5.0 \\
\hline
\end{tabular}


Table 2 - Main shoot height (MSH), shoot system total length (SSTL), and hypocotyl diameter (HD) of Araucaria angustifolia seedlings at 94, 180 and 300 days of growth in different ratios of sand and sludge from rice parboiling wastewater treatment.

Tabela 2 - Altura da parte aérea (MSH), comprimento total da parte aérea (SSTL), e diâmetro do hipocótilo (HD) das mudas de Araucaria angustifolia aos 94, 180 e 300 dias de cultivo em diferentes proporções de areia e lodo de estação de tratamento de efluente de parboilização de arroz.

\begin{tabular}{|c|c|c|c|c|c|c|c|c|c|}
\hline & MSH & & & SSTL & & & HD & & \\
\hline Treatment/Days & 94 & 180 & 300 & 94 & 180 & 300 & 94 & 180 & 300 \\
\hline T1 & $15.09 \mathrm{ab}$ & $19.73 b$ & $18.69 \mathrm{c}$ & $15.09 \mathrm{ab}$ & $29.03 b$ & $30.68 \mathrm{c}$ & $0.60 \mathrm{~ns}$ & $0.60 \mathrm{~ns}$ & $0.60 \mathrm{c}$ \\
\hline $\mathbf{T 2}$ & $16.01^{\mathrm{a}}$ & $26.01 \mathrm{a}$ & $33.86 \mathrm{ab}$ & $16.01^{\mathrm{a}}$ & $48.49 \mathrm{a}$ & $116.07 \mathrm{ab}$ & 0.61 & 0.64 & $0.85 \mathrm{a}$ \\
\hline T3 & $14.73 \mathrm{ab}$ & $25.87 \mathrm{a}$ & $35.85 \mathrm{a}$ & $14.73 \mathrm{ab}$ & $40.74 a$ & $107.11 \mathrm{ab}$ & 0.61 & 0.61 & $0.78 \mathrm{ab}$ \\
\hline T4 & $15.94^{\mathrm{a}}$ & $28.62 \mathrm{a}$ & $34.25 \mathrm{ab}$ & $15.94^{\mathrm{a}}$ & $51.89 \mathrm{a}$ & $131.17 \mathrm{a}$ & 0.59 & 0.65 & $0.75 \mathrm{ab}$ \\
\hline T5 & $13.00 \mathrm{~b}$ & $25.67 \mathrm{a}$ & $29.08 b$ & $13.00 \mathrm{~b}$ & $45.60 \mathrm{a}$ & $83.03 \mathrm{~b}$ & 0.55 & 0.64 & $0.73 b$ \\
\hline
\end{tabular}

these variables, the longer the period of development, the more promising for $A$. angustifolia shoot growth are the mixtures of sludge and sand. In this study, at both 94 and 180 days, values of hypocotyl diameter had no significant differences. At 300 days, values for hypocotyl diameter ranged from $0.60 \mathrm{~cm}$ to $0.85 \mathrm{~cm}$, which the smallest value was observed in $\mathrm{T} 1$, and the greatest, in T2, T3 and T4 (Table 2).

No significant differences were observed for main root length at 94 and 180 days (Table 3). At 300 days, $\mathrm{T} 4$ had the lowest value $(23.5 \mathrm{~cm})$ for this avaliation, which was significantly different from $\mathrm{T} 2(32.93 \mathrm{~cm})$, the greatest value. Despite of the size constraint in the bags used for cultivation, no coiling of the main root was observed.

The highest values for the number of lateral roots at 180 and 300 days were observed in T1 and T2, both treatments with the highest proportion of sand (100\% and $75 \%$, respectively) (Table 3 ). The values for lateral roots average length at 94 and 180 days were not significantly different between the treatments, yet, at 300 days, T1, T2, and T3 provided the highest values, ranging from $6.96 \mathrm{~cm}$ and $7.91 \mathrm{~cm}$ (Table 3).

The results for main root length, number of lateral roots, and lateral roots average length corroborate those found for root system total length (Table 3). On the whole, the treatments with higher proportion of sludge (ranging from $50 \%$ to $100 \%$; T3, T4 and T5) provided the lowest values for root system total length in the periods of evaluation, as there were fewer and shorter lateral roots, especially in the last period of evaluation.

Only sand as substrate (T1) provided the lowest shoot fresh matter (Table 4) and shoot dry matter at 300 days (Table 5), which corroborate the results found for shoot length and shoot system total length (Table 2). Substrates containing sludge showed values ranging between $25.5 \mathrm{~g}$ and $37.01 \mathrm{~g}$ for fresh matter, and $7.04 \mathrm{~g}$ and $10.62 \mathrm{~g}$ for dry matter.

Table 3 - Main root length (MRL), number of lateral roots (NLR), lateral roots average length (LRAL), and root system total length (RSTL) of Araucaria angustifolia seedlings at 94, 180 and 300 days of growth in different ratios of sand and sludge from rice parboiling wastewater treatment.

Tabela 3 - Comprimento da raiz principal (MRL), número de raízes laterais (NLR), comprimento médio das raízes laterais (LRAL) e comprimento total do sistema radicular (RSTL) de mudas de Araucaria angustifolia aos 94, 180 e 300 dias de cultivo em diferentes proporções de areia e lodo de estação de tratamento de efluente de parboilização de arroz.

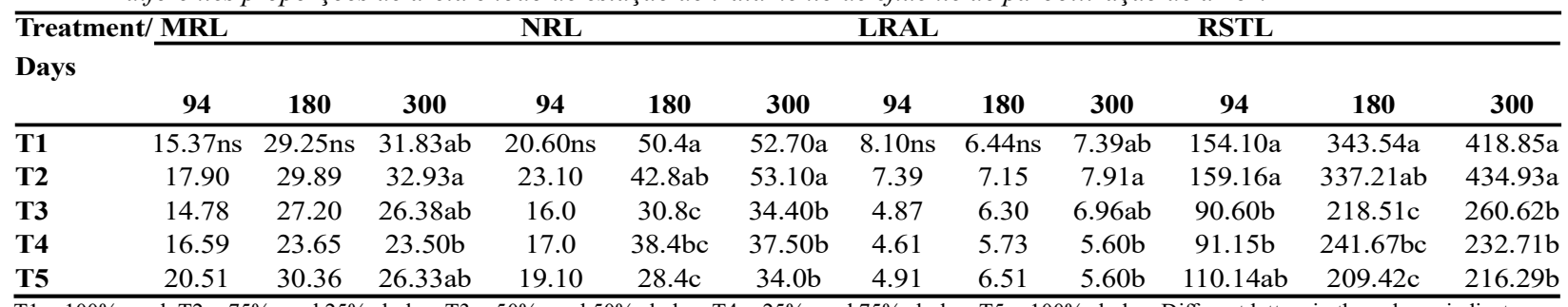

$\mathrm{T} 1=100 \%$ sand; $\mathrm{T} 2=75 \%$ sand $25 \%$ sludge; $\mathrm{T} 3=50 \%$ sand $50 \%$ sludge; $\mathrm{T} 4=25 \%$ sand $75 \%$ sludge; $\mathrm{T} 5=100 \%$ sludge. Different letters in the column indicate significant differences according to Tukey test at $5 \%$ probability. Columns with no letters do not differ statistically (ns).

$T 1=100 \%$ areia $; T 2=75 \%$ areia $25 \%$ lodo; $T 3=50 \%$ areia $50 \%$ lodo; $T 4=25 \%$ areia $75 \%$ lodo; $T 5=100 \%$ lodo. Letras diferentes na coluna indicam diferenças significativas de acordo com o teste de Tukey a $5 \%$ de probabilidade. Colunas sem letras não possuem diferença significativa (ns). 
Table 4 - Shoots fresh matter (SFM), main root fresh matter (MRFM), and lateral roots fresh matter (LRFM), for Araucaria angustifolia seedlings at 94, 180 and 300 days of growth in different ratios of sand and sludge from rice parboiling wastewater treatment.

Tabela 4 - Massa fresca da parte aérea (SFM), massa fresca da raiz principal (MRFM), e massa fresca das raizes laterais (LRFM), de mudas de Araucaria angustifolia aos 94, 180 e 300 dias de cultivo em diferentes proporções de areia e lodo de estação de tratamento de efluente de parboilização de arroz.

\begin{tabular}{lccccccrrr}
\hline & SFM (g) & \multicolumn{3}{c}{ MRFM (g) } & \multicolumn{3}{c}{ LRFM (g) } \\
\hline Treatment/Days & $\mathbf{9 4}$ & $\mathbf{1 8 0}$ & $\mathbf{3 0 0}$ & $\mathbf{9 4}$ & $\mathbf{1 8 0}$ & $\mathbf{3 0 0}$ & $\mathbf{9 4}$ & $\mathbf{1 8 0}$ & $\mathbf{3 0 0}$ \\
\hline T1 & $3.88 \mathrm{~b}$ & $8.24 \mathrm{~b}$ & $7.91 \mathrm{c}$ & $2.00 \mathrm{~ns}$ & $3.75 \mathrm{~ns}$ & $4.89 \mathrm{~b}$ & $1.25 \mathrm{~ns}$ & $3.32 \mathrm{~ns}$ & $4.53 \mathrm{~b}$ \\
T2 & $5.62 \mathrm{a}$ & $22.47 \mathrm{a}$ & $36.62 \mathrm{a}$ & 1.42 & 4.1 & $8.42 \mathrm{a}$ & 1.10 & 4.67 & $12.42 \mathrm{a}$ \\
T3 & $4.71 \mathrm{ab}$ & $19.16 \mathrm{a}$ & $35.12 \mathrm{ab}$ & 1.38 & 3.14 & $6.36 \mathrm{ab}$ & 0.92 & 3.35 & $6.49 \mathrm{~b}$ \\
T4 & $5.27 \mathrm{ab}$ & $25.65 \mathrm{a}$ & $37.01 \mathrm{a}$ & 1.39 & 3.32 & $4.95 \mathrm{~b}$ & 0.70 & 3.51 & $5.06 \mathrm{~b}$ \\
T5 & $3.71 \mathrm{~b}$ & $20.24 \mathrm{a}$ & $25.5 \mathrm{~b}$ & 1.45 & 3.73 & $5.57 \mathrm{~b}$ & 0.70 & 2.94 & $4.12 \mathrm{~b}$ \\
\hline
\end{tabular}

$\mathrm{T} 1=100 \%$ sand; T2 $=75 \%$ sand $25 \%$ sludge; T3 = 50\% sand 50\% sludge; T4 = 25\% sand $75 \%$ sludge; T5 $=100 \%$ sludge. Different letters in the column indicate significant differences according to Tukey test at $5 \%$ probability. Columns with no letters do not differ statistically (ns).

$T 1=100 \%$ areia $; T 2=75 \%$ areia $25 \%$ lodo $; T 3=50 \%$ areia $50 \%$ lodo $; 4=25 \%$ areia $75 \%$ lodo; $T 5=100 \%$ lodo. Letras diferentes na coluna indicam diferenças significativas de acordo com o teste de Tukey a $5 \%$ de probabilidade. Colunas sem letras não possuem diferença significativa (ns).

No significant difference between treatments was found for main root fresh matter (Table 4) and main root dry matter (Table 5) at 94 days, whereas, at 300 days, T2 provided the highest values, $8.42 \mathrm{~g}$ for main root fresh matter and $2.89 \mathrm{~g}$ for main root dry matter. T2 also provided the highest values for lateral roots fresh matter (12.42 g; Table 4) and lateral roots dry matter (2.27 g; Table 5) at 300 days, which was significantly different from other treatments.

\section{DISCUSSION}

Data related to the characterization and use of sludge from rice parboiling wastewater treatment plants as alternative substrate for the production of tree species seedlings are scarce in the literature, whereas most of those publications focus on the wastewater treatment system itself but do not mention its sludge disposal. Thus, this work uses as reference studies related to the use of sludge from sewage wastewater and other substrates, many of them on the production of angiosperm species.
According to Gonçalves et al. (2014), main shoot height is a feature commonly used in seedlings evaluation, which allows to estimate plant growth in the field. As stated by Gomes et al. (2012) and Neto (2015), plant height can be influenced by factors such as nutritional levels where, for example, an increased supply of nitrogen favors growth in height. Although nitrogen levels in the substrate mixtures were not measured in this work, the sludge chemical characterization (Table 1) shows that nitrate is present, which may have contributed for A. angustifolia seedlings growth. Nevertheless, Garbin and Dillenburg (2008) attested that this species assimilates inorganic nitrogen preferentially as ammonium. Vieira et al. (2011) noticed that the sludge from rice parboiling wastewater treatment is rich in nitrogen (23.5 $\left.\mathrm{g} \mathrm{kg}^{-1}\right)$ and phosphorus (42.4 $\left.\mathrm{g} \mathrm{kg}^{-1}\right)$, which may support plant growth. In a study with angiosperms, Trigueiro and Guerrini (2014) assigned a gain in height in Schinus terebinthifolia Raddi seedlings to the nitrogen present in the sewage sludge used as substrate. According

Table 5 - Shoots dry matter (SDM), main root dry matter (MRDM), and lateral roots dry matter (LRDM) for Araucaria angustifolia seedlings at 94, 180 and 300 days of growth in different ratios of sand and sludge from rice parboiling wastewater treatment.

Tabela 5 - Massa seca da parte aérea (SDM), massa seca da raiz principal (MRDM), e massa seca das raízes laterais (LRDM) de mudas de Araucaria angustifolia aos 94, 180 e 300 dias de cultivo em diferentes proporções de areia e lodo de estação de tratamento de efluente de parboilização de arroz.

\begin{tabular}{|c|c|c|c|c|c|c|c|c|c|}
\hline & SDM (g) & & & IRDM ( & & & RDM ( & & \\
\hline Treatment/Days & 94 & 180 & 300 & 94 & 180 & 300 & 94 & 180 & 300 \\
\hline T1 & $0.97 \mathrm{ab}$ & $2.87 \mathrm{~b}$ & $2.81 \mathrm{c}$ & $0.45 \mathrm{~ns}$ & $1.19 \mathrm{a}$ & $1.74 b$ & $0.13 \mathrm{a}$ & $0.69 \mathrm{~ns}$ & $0.88 b$ \\
\hline $\mathbf{T 2}$ & $1.21 \mathrm{a}$ & $5.89 a$ & $10.62 \mathrm{a}$ & 0.27 & $1.09 \mathrm{ab}$ & $2.89 \mathrm{a}$ & $0.09 \mathrm{ab}$ & 0.7 & $2.27 \mathrm{a}$ \\
\hline T3 & $0.99 \mathrm{ab}$ & $4.71 \mathrm{a}$ & $9.82 \mathrm{ab}$ & 0.38 & $0.94 \mathrm{ab}$ & $1.91 \mathrm{~b}$ & $0.05 \mathrm{ab}$ & 0.6 & $1.13 \mathrm{~b}$ \\
\hline T4 & $1.12 \mathrm{ab}$ & $6.4 \mathrm{a}$ & $9.89 \mathrm{ab}$ & 0.27 & $0.89 b$ & $1.59 b$ & $0.02 b$ & 0.58 & $0.95 b$ \\
\hline T5 & $0.79 b$ & $5.01 \mathrm{a}$ & $7.04 b$ & 0.25 & $0.98 \mathrm{ab}$ & $1.57 \mathrm{~b}$ & $0.03 b$ & 0.49 & $0.72 b$ \\
\hline
\end{tabular}

significant differences according to Tukey test at $5 \%$ probability. Columns with no letters do not differ statistically (ns).

$T 1=100 \%$ areia $; T 2=75 \%$ areia $25 \%$ lodo; $T 3=50 \%$ areia $50 \%$ lodo; $T 4=25 \%$ areia $75 \%$ lodo; $T 5=100 \%$ lodo. Letras diferentes na coluna indicam diferenças significativas de acordo com o teste de Tukey a $5 \%$ de probabilidade. Colunas sem letras não possuem diferença significativa (ns). 
to Abreu et al. (2019), treatments with higher levels of biosolids and, consequently, greater amounts of nutrients, showed better results for S. terebinthifolia seedlings main shoot height.

The sludge supplies organic matter, increasing water and nutrients retainment. According to Gomes et al. (2012), sewage sludge associated to commercial substrate and subsoil provided greater height and root dry matter in Tectona grandis L.f. seedlings. For Chamaecrista desvauxii (Collad.) Killip seedlings, the combination of $60 \%$ sewage sludge $+20 \%$ carbonized rice peel $+20 \%$ in natura coffee straw provided greater growth (Caldeira et al., 2013). In the assessment of Psidium cattleyanum Sabine plantlets growth, Marques et al. (2018) observed higher seedlings were produced with $40 \%$ and $60 \%$ sewage sludge combined with organic compost. Treatments containing 20\% sewage sludge $+80 \%$ sand sediment, and $60 \%$ sewage sludge $+40 \%$ sand sediment provided greater average height, average stem diameter and average number of leaves in S. terebinthifolia (Mendonça et al., 2019).

In this study, the sludge from rice parboiling wastewater treatment provided better results when mixed with sand. Sand may have benefited plantlets growth by enabling better water draining and improving organic matter and nutrient supply from the sludge. According to Delarmelina et al. (2014), to support and facilitate plant growth, the substrate should enable appropriate aeration, and proper water draining and retainment balance, without causing soaking. However, A. angustifolia plants did not show satisfactory growth when the substrate was only sand. Corroborating this study, Garcia et al. (2012) noticed that the ideal growth of Bactris gasipaes Kunth seedlings was not achieved using only sand as substrate, and the authors emphasized its use combined with other materials. According to Alvino and Rayol (2007), sand is poor at maintaining moisture, has low water retention and distribution, besides being nutritionally poor, which may impair plant growth in height. According to Wendling and Delgado (2008), $A$. angustifolia seedlings are ready to use when they reach between 13 and $30 \mathrm{~cm}$ height, which varies depending on the vessel used for cultivation. In this study, seedlings grown in substrate containing sludge were over $25 \mathrm{~cm}$ height at 180 days.

For Ritchie et al. (2010), the hypocotyl diameter is an important morphologic trait to estimate plant growth and predict its performance at field, depending on the variations to which each species is exposed to. Dillenburg et al. (2010) noticed that while $A$. angustifolia seeds were attached to the plants, the hypocotyl mass increased, followed by a decrease, confirming that the hypocotyl is a drain for the seed stocks, regardless of the presence or absence of light. In their work with the species, Franco and Dillenburg (2007) observed that the plant retained a bond with the seed for 80 to 120 days, then changing from a dependence state to autonomy. That is, the plantlets were attached to the seeds and part of their reserves were transferred to the hypocotyls. As no difference in the variable was observed at 94 and 180 day, it is assumed that, until this time, the stocks that have moved from the seed to the hypocotyl have had no effect on its diameter. The ideal hypocotyl diameter for forest species ranges from 0.5 to $1.0 \mathrm{~cm}$ (Gonçalves et al., 2000).

According to Trigueiro and Guerrini (2014), and Siqueira et al. (2018), substrates should have physical and chemical properties that enable proper plant development, including a fine root system structure. In general, this study showed greater root growth in substrates containing greater sand ratio. These results may be due to the fact that sand is more porous and has low nutrients content (Picolotto et al., 2007), which requires roots to extend in search of nutrients, including $\mathrm{T} 2$ and $\mathrm{T} 3$, where the higher sand ratio may have influenced increased lateral roots growth (considering number and length of lateral roots). In a study by Mendonça et al. (2019), S. terebinthifolia plantlets cultivated in $100 \%$ sandy sediment showed greater results in roots rather than in height or stem diameter, compared to substrates made of sewage sludge and sandy sediment. Tillmann et al. (1994) say that there is a trend of increased root length in a substrate with higher porosity, aeration, and water availability. As presented in the results, T2 showed greater shoot growth when compared to T1. Negreiros et al. (2004) state that sand might enable greater plant fitness when mixed with other substrates. The results from the present work corroborate those found by Trigueiro and Guerrini (2014) for S. terebinthifolia, where there was reduced root system development in treatments with higher ratio of sewage sludge, which may be due to the substrate's high density, which reduces the draining and, consequently, the aeration.

Revista Árvore 2021;45:e4510 
In a study with Sesbania virgata (Cav.) Pers., the substrate that produced the higher shoot system dry matter at 150 days $(2.11 \mathrm{~g})$ was a mix of $60 \%$ sewage sludge and $40 \%$ vermiculite (Delarmelina et al., 2014). In one of the few studies using the sludge from rice parboiling wastewater treatment, Vieira et al. (2011) tested the addition of $2.15 \mathrm{~g} \mathrm{Kg}^{-1}$ sludge in maize plants cultivated in plastic vessels containing 4 $\mathrm{Kg}$ of soil and observed a significant increase in plants dry matter after 41 days. Substrates composed by $60 \%$ or $20 \%$ sewage sludge combined with carbonized rice peel and in natura coffee straw provided better results for root dry matter of Chamaecrista desvauxii (Collad.) Killip plants cultivated for 150 days (Caldeira et al., 2013). In another study, Eucalyptus grandis W. Hill seedlings grown in $80 \%$ sewage sludge and $20 \%$ coffee straw showed higher values of root dry matter (Caldeira et al., 2014).

\section{CONCLUSION}

Although plants cultivated in $100 \%$ sand (T1) had greater root growth, they produced lower values for shoot growth variables, like main shoot height and hypocotyl diameter, in comparison with sludge from rice parboiling wastewater treatment plants in different proportions.

Seedlings growing in $100 \%$ sludge (T5) provided slow growth, both for shoots and root system.

The combination of sand and sludge from rice parboiling wastewater treatment plants provided the best overall results, considering shoot and root system variables at 300 days. Furthermore, the ratio $25 \%$ sand $+75 \%$ sludge (T4) could be recommended for the production of $A$. angustifolia seedlings as it exploits a larger amount of sludge.

\section{AUTHOR CONTRIBUTIONS}

F.F.C. and E.S. conceived the ideas and designed the methodology, V.N.B. and F.F.C. performed the experiment and collected the data, F.K.P. analyzed the data. All authors contributed to the writing.

\section{ACKNOWLEDGEMENT}

The authors acknowledge the institution that provided a scientific initiation scholarship for the first author, and the rice company that provided the sludge from rice parboiling wastewater treatment plant. The authors also acknowledge to José Quildo Sampaio Rosa for contributing with plants cultivation and data collection. This research is part of first author's final term paper for an Environmental Management Undergraduate Program.

\section{REFERENCES}

Alvino FO, Rayol BP. Different substrate effects in the germination of Ochroma Pyramidale $(\mathrm{Ca}$ exam.) urb. (Bombacaceae). Ciência Florestal. 2007;17(1):71-5. doi:10.5902/198050981937.

Berilli SS, Quiuqui JPC, Rembinski J, Salla PHH, Berilli APCG, Louzada JM. Utilização de lodo de curtume como substrato alternativo para produção de mudas de café conilon. Coffe Science. 2014; 9(4):472-9. doi:10.25186/cs.v9i4.

Brasil. Portaria n ${ }^{\circ} 443$, de 17 de dez. de 2014 do Ministério do Meio Ambiente. Lista Nacional Oficial de Espécies da Flora Ameaçadas de Extinção, Anexo $\mathrm{n}^{\mathrm{o}} 1$. Diário Ofícial [da União] Brasília, 18 de dez. de 2014.

Caldeira MVW, Delarmelina WM, Faria JCT, Juvanhol RS. Substratos alternativos na produção de mudas de Chamaecrista desvauxii. Revista Árvore. 2013;37(1):31-9. doi:10.1590/S010067622013000100004 .

Caldeira MVW, Gonçalves EO, Trazzi OA, Delarmelina WM, Rocha RLF. Crescimento de mudas de Eucalyptus grandis utilizando lodo de esgoto, fibra de coco e palha de café in natura. Floresta. 2014;44(2):195-206. doi:10.5380/ rf.v44i2.30170.

Delarmelina WM, Caldeira MVW, Faria JCT, Gonçalves EO, Rocha RLF. Diferentes substratos na produção de mudas de Sesbania virgata. Floresta e ambiente. 2014;21(2):224-33. doi:10.4322/ floram.2014.027.

Dillenburg LR, Rosa LMG, Mósena M. Hypocotyl of seedlings of the large- seeded species Araucaria angustifolia: an important underground sink of the seed reserves. Trees. 2010;24(4):705-11. doi:10.1007/s00468-010-0440-y.

Faria OLV, Koetz PR, Santos MS, Nunes WA. Remoção de fósforo de efluentes da parboilização de 
arroz por absorção biológica estimulada em reator em batelada sequencial (RBS). Ciência e Tecnologia de Alimentos. 2006;26(2):309-17. doi:10.1590/ S0101-20612006000200013.

Ferreira AG, Handro W. Aspects of seed germination in Araucaria angustifolia (Bert.) O. Revista Brasileira de Botânica. 1979;2:7-13.

Franco AM, Dillenburg LR. Ajustes morfológicos e fisiológicos em plantas jovens de Araucaria angustifolia (Bertol.) Kuntze em resposta ao sombreamento. Hoehnea. 2007;34(2):135-44. doi:10.1590/S2236-89062007000200002.

Fritzsons E, Mantovani LE, Wrege MS. Distribuição da araucária no estado do Paraná (Brasil): fatores climáticos limitantes. Raega: $\mathrm{O}$ Espaço Geográfico em Análise. 2018;44:258-71. doi:10.5380/raega. v44i0.50259.

Gibinski R, Krupek RA. Influência de diferentes fatores sobre a predação de sementes de Araucaria angustifolia (Bertol.) O. Kuntze. Acta Biológica Catarinense. 2016;3(1): 60-68. doi:10.21726/abc. v3i1.239.

Garbin ML, Dillenburg LR. Effects of different nitrogen sources on growth, chlorophyll concentration, nitrate reductase activity and carbon and nitrogen distribution in Araucaria angustifolia. Brazilian Journal of Plant Physiology. 2008;20(4):295-303. doi:10.1590/S167704202008000400005 .

Garcia VA, Modolo VA, Lagôa AMMA, Tucci MLS, Erismann NM, Rodrigues DS. Crescimento de mudas de pupunheira (Bactris gasipaes Kunth) utilizando resíduo de mineração de areia como componente de substratos. Ciência Florestal. 2012;22(3):445-55. doi: $10.5902 / 198050986613$.

Gomes DR, Caldeira MVW, Delarmelina WM, Gonçalves EO, Trazzi PA. Lodo de esgoto como substrato para produção de mudas de Tecnona grandis L. Cerne. 2012;19(1):123-31. doi:10.1590/ S0104-77602013000100015.

Gonçalves EO, Petri GM, Caldeira MVW, Dalmaso TT, Silva AG. Crescimento de mudas de Ateleia glazioviana em substratos contendo diferentes materiais orgânicos. Floresta e Ambiente. 2014;21(3):339-48. doi:10.1590/2179-8087.029213.
Gonçalves JLM, Santerelli EG, Neto SPM, manara MP. Produção de mudas de espécies nativas: substrato, nutrição, sombreamento e fertilização. In: Gonçalves JLM, Benedetti V, editors. Nutrição e fertilização florestal. Piracicaba: IPEF; 2000. p. 309350. ISBN 8590135810.

International Union for Conservation of Nature and Natural Resources - IUCN. The Red List of Threatened Species. 2018. [acessado em 15 de abr. 2018]. Disponível em: http://www.iucnredlist.org/.

Kumar A, Priyadarshini R, Roy A, Dasgupta D, Madal T. Técnicas atuais no tratamento de efluentes de fábricas de arroz: Oportunidades emergentes para reutilização de resíduos e conversão de resíduos para energia. Chemosphere. 2016;164: 404-12.

Marques ARF, Oliveira VS, Boligon AA, Vestena S. Produção e qualidade de mudas de Psidium cattleianum var. cattleianum Sabine (Myrtaceae) em diferentes substratos. Acta Biológica Catarinense. 2018;5(1):5-13. doi:10.21726/abc.v5i1.374.

Mendonça AMC, Dias GS, Nascimento AVS, Campos JA, Santana MC, Júnior CDS, et al. Utilização do lodo de esgoto na produção de mudas de Schinus terebinthifolius Raddi (Anacardiaceae). Scientia Plena. 2019;15(8):1-10. doi:10.14808/sci. plena.2019.081201.

Nadaleti WC, Lourenço VA, Schoeler GP, Santos RF, Vieira BM, Leandro D, et al. Temperaturas mesófilas e termófilas na produção de biogás através de efluente da parboilização do arroz. Revista Brasileira de Engenharia e Sustentabilidade. 2018;5(1): 17-21. doi:10.15210/rbes.v5i1.12540.

Negreiros JRS, Álvares VS, Braga LR, Brucknerc H. Diferentes substratos na formação de mudas de maracujazeiro-amarelo. Ceres. 2004;51(294): 243345 .

Oliveira MC, Ogata RS, Andrade GA, Santos DS, Souza RM, Guimarães TG, et al., editors. Manual de viveiro e produção de mudas: espécies arbóreas nativas do Cerrado. Brasília: Embrapa CerradosRede de Sementes do Cerrado; 2016. ISBN 9788599887165 .

Paraginski RT, Zieglerm V, Talhamento A, Elias MC, Oliveira M. Propriedades tecnológicas e de cocção em grãos de arroz condicionados em diferentes 
temperaturas antes da parboilização. Brazilian Journal of Food Technology. 2014;17(2):146-453. doi:10.1590/bjft.2014.021.

Picolotto L, Bianchi VJ, Gazolla Neto A, Fachinello JC. Diferentes misturas de substratos na formação de mudas de pessegueiro, em embalagem. Scientia Agraria. 2007;8(2): 119-25. doi: 10.5380/rsa. v8i2.8375.

Pierin Neto L. Influência do recipiente na qualidade de mudas de Euterpe edulis Martius (juçara) E Araucaria angustifolia (Bertol.) Kuntze (araucária) [trabalho de conclusão de curso]. Curitiba, PR: Universidade Federal do Paraná. 2015.

R Core Team. R: A language and environment for statistical computing. R Foundation for Vienna, Austria: Statistical Computing; 2019.

Ritchie GA, Landis TD, Dumroese RK, Haase DL. Assessing plant quality. In: Landis TD, Dumroese RK, Haase DL, editors. Seedling processing, storage and outplanting. Washington: U. S. Department of Agriculture Forest Service; 2010. p. 17-81. ISBN: 9781782662419.

Siqueira DP, Carvalho GCMW, Barroso CDG, Marciano CR. Lodo de esgoto tratado na composição de substrato para produção de mudas de Lafoensia glyptocarpa. Floresta. 2018;48(2): 277-84. doi: $10.5380 /$ rf.v48i2.55795.

Tillmann MAA, Cavariane C, Piana Z, Minami K. Comparação entre diversos substratos no enraizamento de estacas de cróton (Codiaeum variegatum L.). Scientia Agricola. 1994;1(51):17-20. doi:10.1590/S0103-90161994000100003.

Trigueiro RM, Guerrini IA. Utilização de lodo de esgoto na produção de mudas de aroeira-pimenteira. Revista Árvore. 2014;38(4): 657-65. doi: 10.1590/ S0100-67622014000400009.

Vieira DD, Castilhos DD, Castilhos RMV. Atributos do solo e crescimento do milho decorrentes da adição de lodo anaeróbio da estação de tratamento de efluentes da parboilização do arroz. Revista Brasileira de Ciência do Solo. 2011;35(2):535-42. doi:10.1590/S0100-06832011000200022.

Volpe TC. Cinética da hidratação do grão de arroz no processo de parboilização [dissertação]. Curitiba, PR: Universidade Federal do Paraná. Curitiba, 2014. http://hdl.handle.net/1884/36532.

Wendling I, Delgado ME. Produção de mudas de araucária em tubetes. Embrapa FlorestasComunicado Técnico (INFOTECA-E). 2008. http:// www.infoteca.cnptia.embrapa.br/infoteca/handle/ doc/314703. 